\title{
CALIBRATION AND TEST OF THE CROPGRO-DRY BEAN MODEL FOR EDAPHOCLIMATIC CONDITIONS IN THE SAVANAS OF CENTRAL BRAZIL ${ }^{1}$
}

\author{
Elza Jacqueline Leite Meireles ${ }^{2,5 *}$; Antonio Roberto Pereira ${ }^{3,5}$; Paulo Cesar Sentelhas ${ }^{3}$; \\ Luis Fernando Stone ${ }^{4,5}$; Francisco José Pfeilsticker Zimmermann ${ }^{4}$ \\ ${ }_{3}^{2}$ Embrapa Café, Edifício Sede da Embrapa - PqEB, Final da Av. W3 Norte - sala 321 - CEP:70770-901 - Brasília, DF. \\ ${ }^{3}$ Depto. de Ciências Exatas, USP/ESALQ, C.P. 9 - CEP:13418-900 - Piracicaba, SP. \\ ${ }^{4}$ Embrapa Arroz e Feijão, C. P. 179 - CEP: 75375-000 - Santo Antônio de Goiás, GO. \\ ${ }^{5} \mathrm{CNPq}$ Fellow. \\ *Corresponding author <jacqueline.meireles@embrapa.br>
}

ABSTRACT: Simulation models are important tools for the analysis of cultivated systems to estimate the performance of crops in different environments. The CROPGRO- model (DSSAT) was calibrated and validated using Carioca bean (Phaseolus vulgaris L.) to estimate yield and the development of the crop, sown in three row spacings $(0.4,0.5$, and $0.6 \mathrm{~m})$ and two fertilization rates (300 and $500 \mathrm{~kg} \mathrm{ha}^{-1}$ of $4-30-16 \mathrm{~N}-\mathrm{P}-\mathrm{K}$ ), in Santo Antônio de Goiás, GO, Brazil. To calibrate the model a combination of the genetic coefficients that characterize the phenology and morphology of the dry bean crop was used to obtain the best possible fit between predicted and observed anthesis and physiological maturity dates, leaf area index (LAI), total dry matter (TDM), yield components, and grain yield for the $0.6 \mathrm{~m}$ row spacing. To test the model the experimental records of the 0.4 and $0.5 \mathrm{~m}$ row spacings were used. In both, calibration and test, the performance of the model was evaluated plotting observed and predicted values of LAI and TDM versus time, using the $r^{2}$, and the agreement index (d) as statistical criteria. In relation to yield and yield components the percent difference between the observed and predicted data was calculated. The model appeared to be adequate to simulate phenology, grain yield and yield components for the Carioca bean cultivar, related to different levels of fertilization and row spacing, either during calibration or the testing phase. During the test, the grain yield was overestimated by less than $15.4 \%$, indicating a potential use for the calibrated model in assessing climatic risks in this region.

Key words: DSSAT, dry bean, simulation

\section{CALIBRAÇÃO E TESTE DO MODELO “CROPGRO-DRY BEAN” PARA AS CONDIÇÕES EDAFOCLIMÁTICAS DO BRASIL CENTRAL}

RESUMO: Modelos de simulação são importantes ferramentas na análise de sistemas cultivados para estimar a performance da cultura em diferentes ambientes. O modelo CROPGRO- foi calibrado e testado, utilizandose o cultivar Carioca para estimar a produtividade e o desenvolvimento do feijoeiro (Phaseolus vulgaris L.) sob três espaçamentos $\left(0,4,0,5\right.$ e 0,6 m) e duas doses de adubação (300 e $500 \mathrm{~kg} \mathrm{ha}^{-1}$ de 4-30-16 de N-PK), em Santo Antônio de Goiás, GO. A calibração consistiu na modificação dos coeficientes genéticos característicos da fenologia e morfologia do feijoeiro, visando obter os melhores ajustes possíveis entre os dados simulados e os observados a campo das datas de antese e maturação fisiológica, índice de área foliar (IAF), massa de matéria seca total (MMST), componentes de produção e produtividade de grãos para 0 espaçamento de 0,6 m. Para o teste do modelo foram utilizados os dados experimentais correspondentes aos espaçamentos de 0,4 e $0,5 \mathrm{~m}$. Em ambos, calibração e teste, a aferição da performance do modelo foi efetuada plotando-se os valores observados e simulados do IAF e MMST ao longo do tempo (dias após semeadura), e utilizando-se o $r^{2}$ e o índice de concordância (d) como critério estatístico. Para produtividade de grãos e componentes de produção determinou-se a diferença percentual entre os valores observados e simulados. O modelo simulou satisfatoriamente a fenologia, a produtividade de grãos e os componentes de produção, para as diferentes doses de adubação e espaçamentos, tanto na fase de calibração como na de teste. Durante o teste, a produtividade de grãos foi superestimada, no máximo, em $15,4 \%$, indicando 0 potencial do modelo calibrado em futura análise de riscos climáticos.

Palavras-chave: DSSAT, feijoeiro, simulação

\section{INTRODUCTION}

The CROPGRO-Dry Bean model, which is part of the DSSAT system (Decision Support System for Agrotechnology Transfer) and of the IBSNAT project
(International Benchmark Sites Network for Agrotechnology Transfer), is composed of a deterministic and mechanistic model that simulates the duration of vegetative and reproductive stages, accumulation of biomass, and grain yield for a specific cultivar associated

${ }^{1}$ Part of the PhD Thesis of the first author, presented to USP/ESALQ - Piracicaba, SP, Brazil. 
to management practices, soil and climate conditions (Hoogenboom et al., 1994).

Cultivars are represented by a group of genetic coefficients derived from calibrations using data from field experiments. These coefficients describe the genotype characteristics in response to soil and climate conditions, affecting phenology, accumulation of biomass and partitioning of assimilates. To simulate crop phenology, CROPGRO defines 13 stages, each one set when a photothermal accumulator is reached (Jones et al., 1998). The limits of these photothermal accumulators are established through the genetic coefficients. Biomass is divided among the plant organs and its accumulation is regulated by the photosynthesis process, which depends on light interception, photoperiod, temperature, and water and nitrogen supply (Faria et al., 1997a).

Calibrations and tests of simulation models, that are part of the DSSAT, were performed for various crops in Brazil. For the dry bean, for instance, Faria et al. (1997b) calibrated the BEANGRO model for the conditions of Londrina, PR - Brazil, testing its performance under several environmental conditions. Although some modifications were necessary, results indicated that the model is adequate to estimate phenology and grain yield for two cultivars for several sowing dates and moisture regimes, allowing its use for climatic risk and technical and economical viability studies of this crop under arid and irrigated conditions.

Bastos (1999) adapted the CROPGRO model to simulate the cowpea crop (CROPGRO-cowpea) under several management practices in Piauí, Brazil, for several locations and moisture conditions, in order to develop information about irrigation management that offers higher net return.

This work had as purpose to calibrate and test the CROPGRO-Dry Bean model for Carioca dry bean, grown under several row spacings and fertilizer rates, in Santo Antônio de Goiás, GO, Brazil, aiming at its later use to analyze climatic risk for dry bean growing in the Cerrado (Savannah-like) Goiano.

\section{MATERIAL AND METHODS}

The CROPGRO-Dry Bean model, version 2.02, developed by Hoogenboom et al (1994) requires genetic parameters of the cultivar as well as detailed information on soil, climate and crop management. Three files characterize input data of the crop according to the following description: (a) file.ECO, which characterizes the ecotype and contains genetic attributes that discriminate cultivars of determinate and indeterminate growth; (b) file.SPE, that characterizes species and contains coefficients that define the basic composition of tissues and describe the photosynthesis process, respiration, nitrogen assimilation, partition of assimilates, senescence, phenology and growth; (c) file.CUL, which contains particular information on the cultivar such as photoperiod sensitivity, photosynthetic rate, specific leaf area, maximum grain weight, the maximum area of a Trifolium, average number of grains per pod, number of days between emergence and first flower, between first flower and first pod, first flower and first grain, first grain and physiological maturity, and between first flower and the end of leaf expansion. Weather data, such as maximum and minimum air temperature, rainfall and solar radiation, on a daily basis, are in the climate files (STATION.WTH and STATION. CLI).

Soil data such as bulk density, water saturation, field water capacity, permanent wilting point, soil albedo, granolometry analyses, organic $\mathrm{C}$, texture, $\mathrm{pH}$, among others, are in the SOIL.SOL file.

The $X$ file defines all the information on crop management (irrigation, fertilizers, incorporation of residues, crop rotation, and planting date).

This work used a climatologic daily series of maximum and minimum air temperature, rainfall and number of sunshine hours data from 1978 to 1998 obtained at Embrapa - Centro Nacional de Pesquisa de Arroz e Feijão (CNPAF), as well as information on physical, chemical and water characteristics of the local soil, classified as an Oxisol, to generate climate and soil files used in the simulations.

Phenology, grain yield and yield component data used in the calibration and test of the model were obtained by Stone \& Pereira (1994a; 1994b) from a field experiment in which the three row spacings were evaluated $(E 1=0.4 \mathrm{~m} ; E 2=0.5 \mathrm{~m}$; and $E 3=0.6 \mathrm{~m})$ and two fertilization effects $\left(A 1=300 \mathrm{~kg} \mathrm{ha}^{-1}\right.$; and $A 2=500 \mathrm{~kg}$ $\mathrm{ha}^{-1}$ of the formula 4-30-16) for the Carioca bean cultivar yield (Meireles, 2000).

In this experiment, sowing was on July $1^{\text {st }}, 1990$ under a center pivot at Embrapa - CNPAF (Fazenda Capivara), in Santo Antônio de Goiás, GO, Brazil (16²8' S; 49¹7' W; 823 m). Stone \& Pereira (1994a; 1994b) managed the irrigation in such a way that the water potential in the soil, measured at $0.15 \mathrm{~m}$ depth, was not higher than $0.03 \mathrm{MPa}$, as recommended by Stone at al. (1998).

The calibration of the CROPGRO-Dry Bean model consisted of the modification of a number of genetic coefficients such as the number of days between emergence and first flower, first flower and first pod, first flower and first grain, first grain and physiological maturity, and between first flower and the end of leaf expansion, maximum photosynthetic rate, specific leaf area, maximum area of a Trifolium, maximum grain weight, average number of grains per pod to achieve the best possible adjustments between predicted and observed data according to the method proposed by Boote (1994).

First, flowering and physiological maturity dates were adjusted, altering the genetic coefficients related to the crop phenology in a way that predicted and observed values were closer to the experimental values. 
Subsequently, leaf area index, dry matter yield, one grain weight, number of grains per pod, number of seeds per $\mathrm{m}^{2}$, and grain yield adjustments were made. At this stage, sequential values were attributed to plant parameters, and the model was run several times until predicted values were closer to those observed for the row spacing of $0.6 \mathrm{~m}$ and the two fertilizations.

The estimates of the number of days to first flower, pod, and grain as well as to physiological maturity in the simulations were based on the concept of a physiological day (Boote et al., 1998). The relationship between the physiological day (PD) and the calendar day (Day) is defined by the equation:

$P D /$ Day $=f(T) \cdot f(P) \cdot f(W)$

where $f(T)$ is the growth restriction factor due to air temperature, $f(P)$ is the growth restriction factor due to photoperiod and $f(W)$ is the growth restriction factor due to water stress, all three undimensional.

For optimal temperature, photoperiod, and soil water $f(T), f(P)$, and $f(W)$ are $=1$ and in this case the physiological day equals the calendar day; for other conditions PD $\leq$ Day. Equation (1) is based on basal temperature $(\mathrm{Tb})$, optimal temperatures $\left(\mathrm{To}_{1}\right.$ and $\left.\mathrm{To}_{2}\right)$, and limit temperature $(\mathrm{TI})$ values for each phase (Table 1 ). In this work, $f(P)$ and $f(W)$ were considered to be one, since the dry bean crop was not affected by photoperiod, and there was no water restriction during simulation.

In the test, the values predicted by the calibrated model were compared to those measured, not used in the calibration (row spacings of $0.4 \mathrm{~m}$ and $0.5 \mathrm{~m}$ ) as suggested by Jones et al. (1987) and Hoogenboom et al. (1992). This comparison was related to anthesis and physiological maturity dates, leaf area index, total dry matter, yield components, and yield.

The performance of the model was evaluated according to graphic and statistical methods, plotting observed and predicted values of leaf area index (LAI) and total dry matter (TDM) versus time. As statistical criteria, the regression analysis - which shows the precision of the estimates through coefficient of determination $\left(r^{2}\right)$ - and the index of agreement $(d)$ (Wilmott et al., 1985) - which indicates the accuracy of estimates in relation to observed values - were used,

Table 1 - Basal temperature (Tb), optimal temperatures (To, e $\mathrm{To}_{2}$ ) and limit temperature ( $\left.\mathrm{TI}\right)$ for the dry bean crop cycle according to the CROPGRO-Dry Bean model, v. 2.02.

\begin{tabular}{|c|c|c|c|c|}
\hline Stage & $\mathrm{Tb}$ & $\mathrm{To}_{1}$ & $\mathrm{To}_{2}$ & $\mathrm{TI}$ \\
\hline & \multicolumn{4}{|c|}{ - } \\
\hline Vegetative & 4.0 & 27.0 & 35.0 & 45.0 \\
\hline $\begin{array}{l}\text { Before reproductive } \\
\text { stage }\end{array}$ & 5.0 & 22.5 & 35.0 & 45.0 \\
\hline $\begin{array}{l}\text { After reproductive } \\
\text { stage }\end{array}$ & 0.0 & 18.0 & 35.0 & 45.0 \\
\hline
\end{tabular}

Source: Hoogenboom et al. (1994). ranging from zero - which indicates null result - to one - which indicates perfect accuracy. The $d$ index was determined as follows:

$\mathrm{d}=1-\left[\left(\Sigma\left(\mathrm{P}_{\mathrm{i}}-\mathrm{O}_{\mathrm{i}}\right)^{2} / \Sigma\left(\left|\mathrm{P}_{\mathrm{i}}-\mathrm{O}\right|+\left|\mathrm{O}_{\mathrm{i}}-\mathrm{O}\right|\right)^{2}\right]\right.$

where: $O_{i}=$ measured value of LAI and TDM, $P_{i}=$ estimated value of $L A I$ and TDM, $O=$ average of measured values of LAI and TDM, and $\mathrm{i}=$ number of observations.

Analysis of variance was run for predicted and observed LAI and TDM values of the dry bean crop for all row spacings and fertilizations. For grain yield and yield components the percent difference between the observed and predicted data was calculated.

The model still does not consider the effects of pests and diseases, which affect the experimental results. In order to minimize this problem, the experimental values are shown as averages and standard deviations. The simulation in the interval of standard deviation was considered good.

\section{RESULTS AND DISCUSSION}

\section{Calibration of the model}

The combination of the genetic coefficients that better predicted phenology and morphology of Carioca bean is shown in Table 2. With these coefficients, a good fit between the anthesis (44 days after sowing, DAS) and the physiological maturity dates (82 DAS) predicted and observed in the field for the two fertilization rates. This is regulated by genetic characteristics and affected by temperature. There was no effect of fertilization rate. These results are different from those of Martins et al. (1994) in the autumn-winter season in the region of Lavras, MG, Brazil, where Carioca bean needed 64 DAS to reach anthesis and 104 DAS to reach physiological maturity. In Lavras, there was an extension of the crop cycle due to colder temperatures as compared to Santo Antônio de Goiás.

The simulation of TDM was good with good prediction, as well as an almost perfect accuracy of TDM estimates in relation to the observed values, $d=0.99$ (Figure 1a) and $d=0.98$ (Figure 1b). A better adjustment for fertilization A1 (Figure 1a) during almost the whole cycle. For fertilization A2 (Figure 1b), the model underestimated until the physiological maturity (70 DAS) and an overestimated thereafter. A similar situation was described by White et al. (1995) in the BEANGRO model applied to the Carioca bean cultivar with overestimates during the grain filling period.

Comparing the predicted and observed LAI and their respective standard deviations, the adjustments were satisfactory, with $r^{2}=0.89$ for fertilization $A 1$ and 0.84 for A2. Although the accuracy of the estimates of $\mathrm{LAl}$, expressed by $r^{2}$, was lower for the two fertilization, rates the accuracy of the estimates of LAI in relation to the observed values ranyed from 0.94 to 0.95 for the 
smaller and larger fertilization, rates respectively. There was an underestimate until approximately 43 DAS, comprehending the beginning of flowering, with subsequent overestimate (Figures $2 a$ and $2 b$ ). The overestimates may be related to pests and diseases, not considered by the model.

The predicted maximum LAI was about $6 \%$ higher than the observed (3.72) with a delay of 3 days for fertilization $A 1$. In relation to $A 2$, the predicted maximum LAl occurred 4 days in advance, being about $7 \%$ smaller (5.19). Adequate water, solar energy and nutrient conditions favored the most intense vegetative growth of the crop, resulting in higher LAl for the larger fertilization. High maximum LAI was also obtained by Urchei (1996) with cultivar Aporé under a no-till system (5.13) and in conventional till system (4.19) about 58 days after emergence, in the flowering stage, in the region of Senador Canedo, GO, Brazil.
Using $F$ test, no differences between the predicted and observed LAI and TDM values for dry bean, row spacing of $0.6 \mathrm{~m}$ and fertilizations $\mathrm{A} 1$ and $\mathrm{A} 2$, were.

Yield prediction was good found with a difference of $+6,1 \%$ for fertilization A2 (2321 $\mathrm{kg} \mathrm{ha}^{-1}$ obs. $/ 2463 \mathrm{~kg} \mathrm{ha}^{-1} \mathrm{sim}$.), and $+7.2 \%$ for fertilization $\mathrm{A} 1$ (2218 kg ha-1 obs. $/ 2377 \mathrm{~kg} \mathrm{ha}^{-1} \mathrm{sim}$.). The number of grains per pod increased with the fertilization rate $(\mathrm{A} 1=4.9 ; \mathrm{A} 2=5.1)$, which was also reported by Garrido (1998), and well predicted in our simulation (Table 3). However, the mass of 100 grains (M100) was reduced with the increase in fertilization rate $(\mathrm{A} 1$ $=2.30 \times 10^{-2} \mathrm{~kg} / 100$ grains; $A 2=2.09 \times 10^{-2} \mathrm{~kg} / 100$ grains), contrary to the findings of Garrido (1998), a positive linear relationship between $\mathrm{N}$ rate and $\mathrm{M} 100$, where was found with increases of $3.4 \times 10^{-5} \mathrm{~kg} \mathrm{~kg}^{-1}$ applied N.

Table 2 - Modified genetic coefficients resulted from the calibration of the CROPGRO-Dry Bean model for the Carioca dry bean cultivar, row spacing of $0.6 \mathrm{~m}$, and fertilization rates of 300 and $500 \mathrm{~kg} \mathrm{ha}^{-1}$, in Santo Antônio de Goiás, GO, Brazil.

\begin{tabular}{|c|c|c|c|}
\hline \multirow{3}{*}{ Genetic coefficients } & \multirow{3}{*}{$\begin{array}{c}\text { CROPGRO- } \\
\text { Dry Bean }\end{array}$} & \multicolumn{2}{|c|}{ Modified values } \\
\hline & & \multicolumn{2}{|c|}{ Fertilization } \\
\hline & & 300 & 500 \\
\hline & & \multicolumn{2}{|c|}{------------ kg ha"-1 ----------- } \\
\hline Number of days between emergency and first flowe (PD $\left.{ }^{1}\right)$ & 33.5 & $30^{2}$ & 30 \\
\hline Number of days between first flower and first pod (PD) & 3 & $9^{3}$ & 9 \\
\hline Number of days between first flower and first grain (PD) & 11 & $13^{3}$ & 13 \\
\hline Number of days between first grain and physiological maturity (PD) & 24 & $23^{3}$ & 23 \\
\hline Number of days between first flower and the end of leaf expansio (PD) & 18 & $55^{3}$ & 55 \\
\hline Photosynthetic maximum rate $\left(10^{-6} \mathrm{~kg} \mathrm{CO}_{2} \mathrm{~m}^{-2} \mathrm{~s}^{-1}\right)$ & 0.9 & $1.0^{4}$ & 1.1 \\
\hline Specific leaf area in ambiental growth conditions $\left(\mathrm{m}^{2} \mathrm{~kg}^{-1}\right)$ & 27 & $29^{4}$ & 37 \\
\hline Maximum area of a trifolium $\left(10^{-4} \mathrm{~m}^{2}\right)$ & 133 & $100^{2}$ & 100 \\
\hline Maximum grain weight $\left(10^{-4} \mathrm{~kg}\right)$ & 2.50 & $2.73^{2}$ & 2.51 \\
\hline Average number of grains per pod & 5.0 & $4.9^{2}$ & 5.1 \\
\hline
\end{tabular}

${ }^{1}$ Physiological day (PD) - it corresponds to the calendar day when in optimal conditions for plant development.

${ }^{2}$ Experimental values, Embrapa - Centro Nacional de Pesquisa de Arroz e Feijão, Santo Antônio de Goiás, GO, Brazil.

${ }^{3}$ Portes, T. A. Personal comunication. Universidade Federal de Goiás, Goiânia, GO, Brazil, 1999.

${ }^{4}$ Genetic coefficient file "gcrules.fle" of DSSAT 3.5.
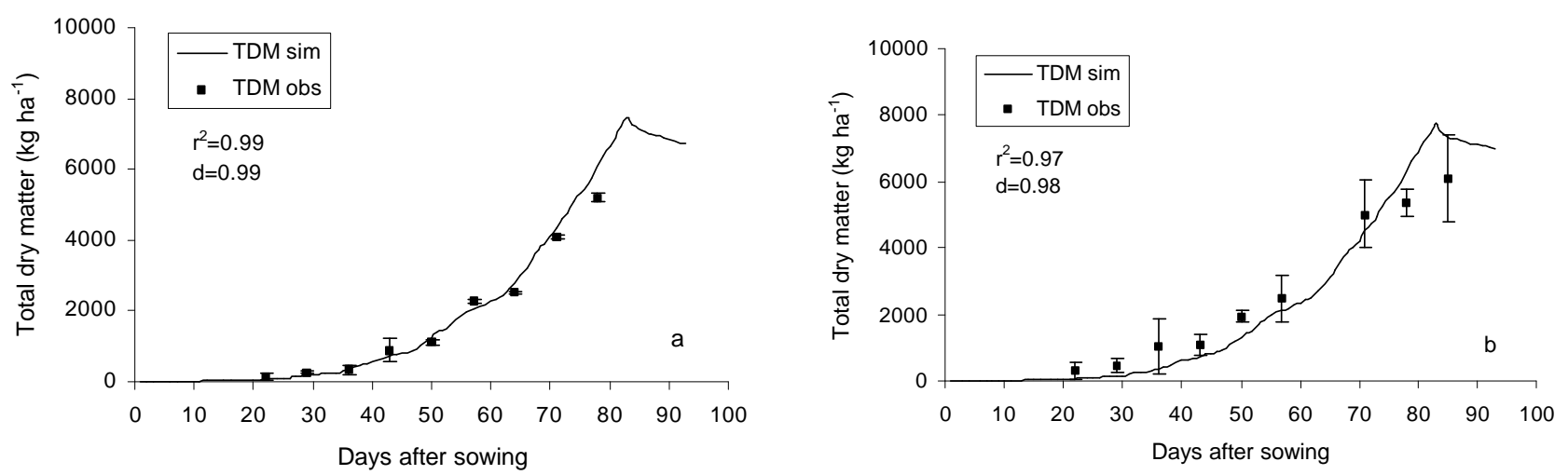

Figure 1 - Observed and predicted total dry matter (TDM) of the dry bean crop, Carioca cultivar, row spacing of $0.6 \mathrm{~m}$, and fertilization of 300 (a) and $500 \mathrm{~kg} \mathrm{ha}^{-1}$ (b), at Santo Antônio de Goiás, GO, Brazil. The amplitude of the vertical lines corresponds to standard deviation. 


\section{Testing the model}

When testing the calibrated model for row spacings $\mathrm{E} 1$ and $\mathrm{E} 2$, no differences between the predicted and observed data at the anthesis (44 DAS) for the two fertilizations were found and the date of the predicted physiological maturity ( 81 DAS) differed only by one day in relation to that observed for $E 1$ and $A 1$. These results show a good performance of the CROPGRO-Dry Bean model when simulating the dry bean phenology.

TDM was underestimated during the whole cycle for the row spacing E1 with fertilization A1 (Figure 3a). There was a difference in phase between the predicted and observed values. Nonetheless, $r^{2}=0.90$ and $d=0.91$ were satisfactory. In relation to the fertilization rate $A 2$, the simulation was a little better because the standard deviations of the observed values were larger, including the predicted curve during most part of the cycle, resulting $r^{2}=$ 0.94 and $d=0.96$ (Figure $3 b$ ). In relation to the row spacing $\mathrm{E} 2$, the simulation was better with two fertilizations, resulting in $r^{2}=0.97$ and 0.95 , and $d=0.99$ and 0.96 (Figure 4).

At the end of the cycle, the maximum values of TDM were overestimated for fertilization A2. Overestimates of TDM were also obtained by White et al. (1995) with the BEANGRO model.

$\mathrm{LAl}$, was underestimated during the whole cycle for treatment E1 A1. However, a $r^{2}$ was 0.91 , indicating a satisfactory precision and $d$ was 0.93 , expressing good accuracy between the predicted and observed data (Figure 5a). Concerning treatment E1 A2, the overestimate was until 55 DAS, including the period of flowering, with subsequent overestimate until the end of the cycle (Figure
$5 b)$. Although the coefficient of determination was lower $\left(r^{2}=0.78\right)$, the index of agreement was satisfactory $(d=$ 0.91 ). These differences may be related to pests and diseases that the model does not consider as well as to the spatial variability of the experimental data. In the case of treatment E2 $A 1$, the underestimate occurred during the vegetative stage and part of the flowering stage, that is, until approximately $50 \mathrm{DAS}$, but after this stage there was an overestimate until the end of the cycle (Figure 6a). A similar situation occurred for treatment E2 A2, with an inversion next to 44 DAS, at the beginning of flowering (Figure $6 \mathrm{~b}$ ). In relation to the coefficients of determination (Figure 6), the accuracy of estimates were reduced with increases in fertilization, as well as the index of agreement $\left(d_{E 2 A 1}=0.99 ; d_{E 2 A 2}=0.91\right)$, showing lower accuracy of the estimates of LAI in relation to the observed values. The narrower row spacing (E1) showed higher maximum LAI, (6.60) for fertilization $\mathrm{A} 1$, and 6.47 for $\mathrm{A} 2$, row spacing $\mathrm{E} 2$ with 4.87 for fertilization $\mathrm{A} 2$ and 3.68 for $\mathrm{A} 1$.

$F$ test, revealed no differences between the predicted and observed LAI and TDM values for row spacings $\mathrm{E} 1$ and $\mathrm{E} 2$ and fertilization $\mathrm{A} 1$ e $\mathrm{A} 2$ were observed.

The predicted yields of grains were higher than those in field under all conditions (Table 4). Differences of $+12.9 \%$ in treatment $\mathrm{E} 1 \mathrm{~A} 1$ and of $+14.7 \%$ for treatment E2 A1 were observed. The difference was of $+10.8 \%$ in treatment E1 A2 whereas in treatment E2 A2 it increased by $+15.4 \%$. Similar results were reported by White et al. (1995) with the BEANGRO model, although with higher overestimates for the same Carioca bean cultivar.

Table 3 - Observed and predicted yield and yield components of the dry bean crop, Carioca cultivar, row spacing of $0.6 \mathrm{~m}$, and fertilization of 300 e $500 \mathrm{~kg} \mathrm{ha}^{-1}$, in the calibration phase of the model, for Santo Antônio de Goiás, GO, Brazil.

\begin{tabular}{|c|c|c|c|c|c|c|}
\hline \multirow{3}{*}{ Component } & \multicolumn{6}{|c|}{ Fertilization (kg ha-1) } \\
\hline & \multicolumn{3}{|c|}{300} & \multicolumn{3}{|c|}{500} \\
\hline & Predicted & Observed & $\operatorname{Dif}(\%)^{1}$ & Predicted & Observed & Dif (\%) \\
\hline Yield $\left(\mathrm{kg} \mathrm{ha}^{-1}\right)$ & 2377 & 2218 & 7.2 & 2463 & 2321 & 6.1 \\
\hline Number of grain/pod & 4.90 & 4.90 & 0 & 5.10 & 5.10 & 0 \\
\hline Weight 100 grains $(\mathrm{kg})$ & $2.30 \times 10^{-2}$ & $2.30 \times 10^{-2}$ & 0 & $2.09 \times 10^{-2}$ & $2.09 \times 10^{-2}$ & 0 \\
\hline
\end{tabular}

${ }^{1}$ Difference $(\%)=[($ Predicted - Observed $) /$ Observed $] \times 100$
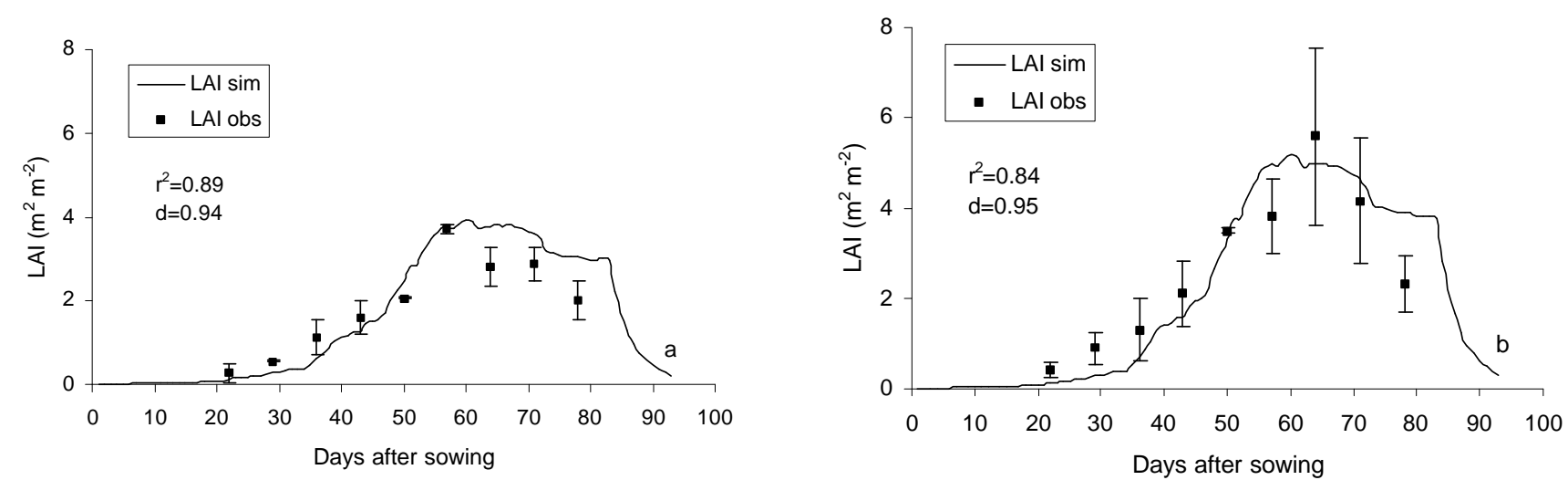

Figure 2 - Observed and predicted leaf area index (LAl) of the dry bean crop, Carioca cultivar, row spacing of $0.6 \mathrm{~m}$, and fertilization of 300 (a) and $500 \mathrm{~kg} \mathrm{ha}^{-1}$ (b), at Santo Antônio de Goiás, GO, Brazil. The amplitude of the vertical lines corresponds to standard deviation. 

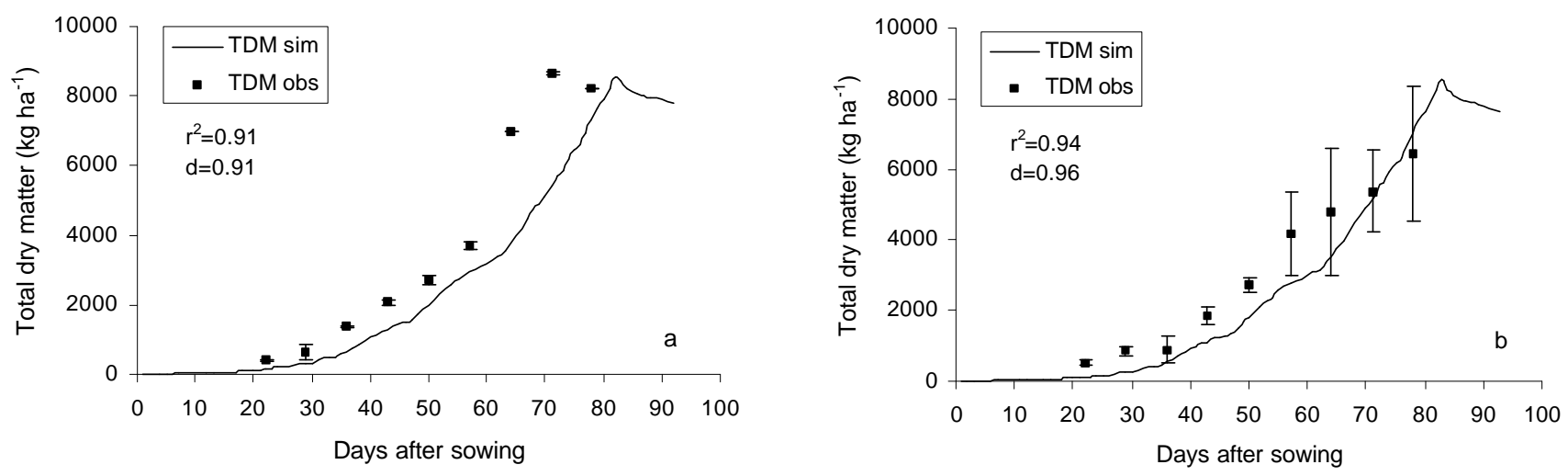

Figure 3 - Observed and predicted total dry matter (TDM) of the dry bean crop, Carioca cultivar, row spacing of $0.4 \mathrm{~m}$, and fertilization of 300 (a) and $500 \mathrm{~kg} \mathrm{ha}^{-1}$ (b), at Santo Antônio de Goiás, GO, Brazil. The amplitude of the vertical lines corresponds to standard deviation.
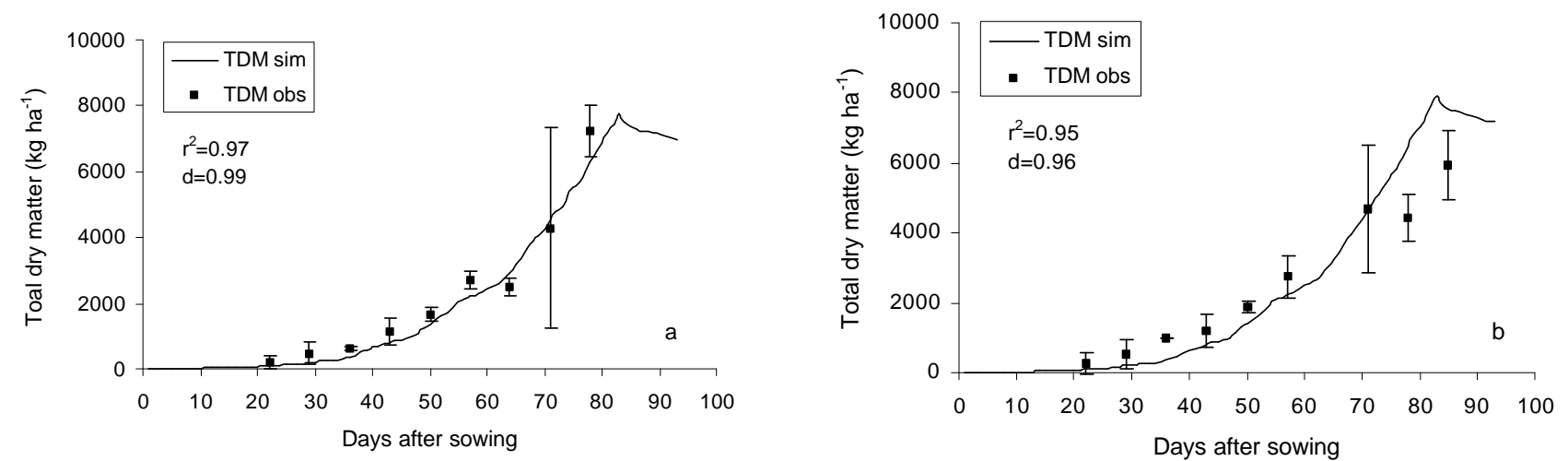

Figure 4 - Observed and predicted total dry matter (TDM) of the dry bean crop, Carioca cultivar, row spacing of $0.5 \mathrm{~m}$, and fertilization of 300 (a) and $500 \mathrm{~kg} \mathrm{ha}^{-1}$ (b), at Santo Antônio de Goiás, GO, Brazil. The amplitude of the vertical lines corresponds to standard deviation.
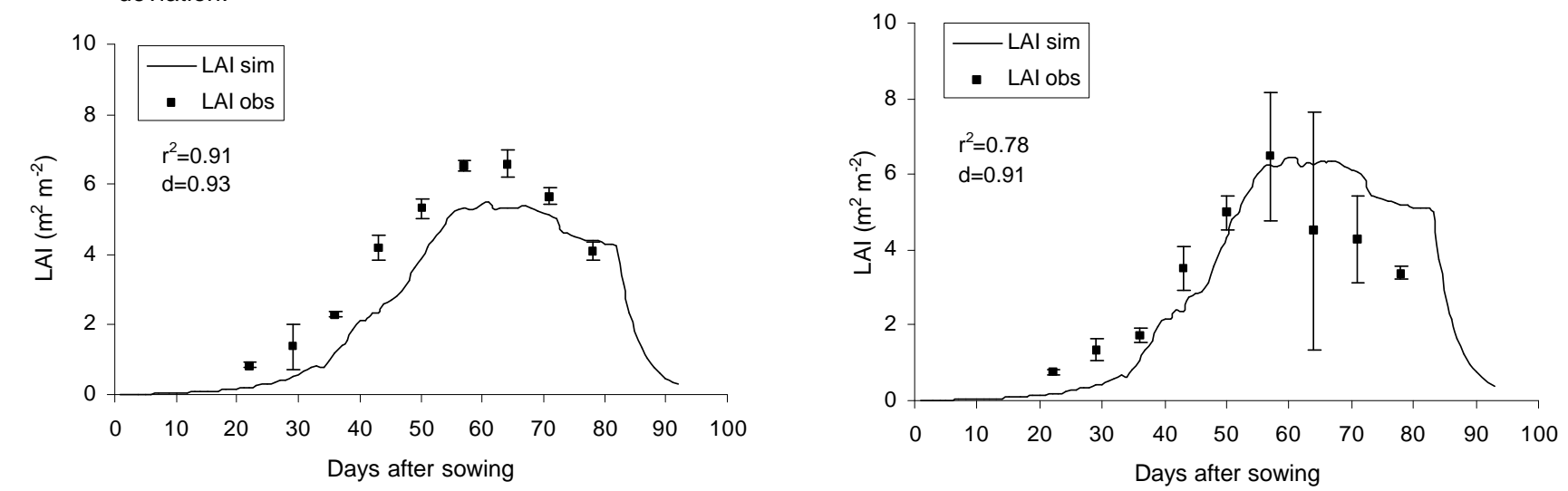

Figure 5 - Observed and predicted leaf area index (LAI) of the dry bean crop, Carioca cultivar, row spacing of $0.4 \mathrm{~m}$, and fertilization 300 (a) and $500 \mathrm{~kg} \mathrm{ha}^{-1}$ (b), at Santo Antônio de Goiás, GO, Brazil. The amplitude of the vertical lines corresponds to standard deviation.

For number of grains per pod, the simulations were almost perfect for all treatments, except for E2 A2 in which the difference was of $+5.2 \%$ (Table 4 ). The number of grains per pod varied little, due to row spacings and populations, similar to that reported by Valério (1998) in the trials made during the rainy season, drought and of winter/spring in the region of Lavras, indicating that it is a yield component little affected by the environment.

For $\mathrm{M} 100$, larger differences between predicted and observed values were found in treatments $E 1 A 1$ with
$+7.5 \%$, and E2 A1 with $+8.5 \%$ (Table 4 ). M100 varied a little between the treatments, from $2.30 \times 10^{-2} \mathrm{~kg} / 100$ grains to $2.11 \times 10^{-2} \mathrm{~kg} / 100$ grains, a result similar to that obtained by Rocha (1991).

The CROPGRO-Dry Bean model, after calibrated and tested for Carioca dry bean, under contrasting row spacings and fertilization rates in Santo Antônio de Goiás, performed well in predicting phenology, yield components, and yield, indicating that it can be used in assessing climatic risks for the cultivation of this crop in the Cerrado Goiano. 

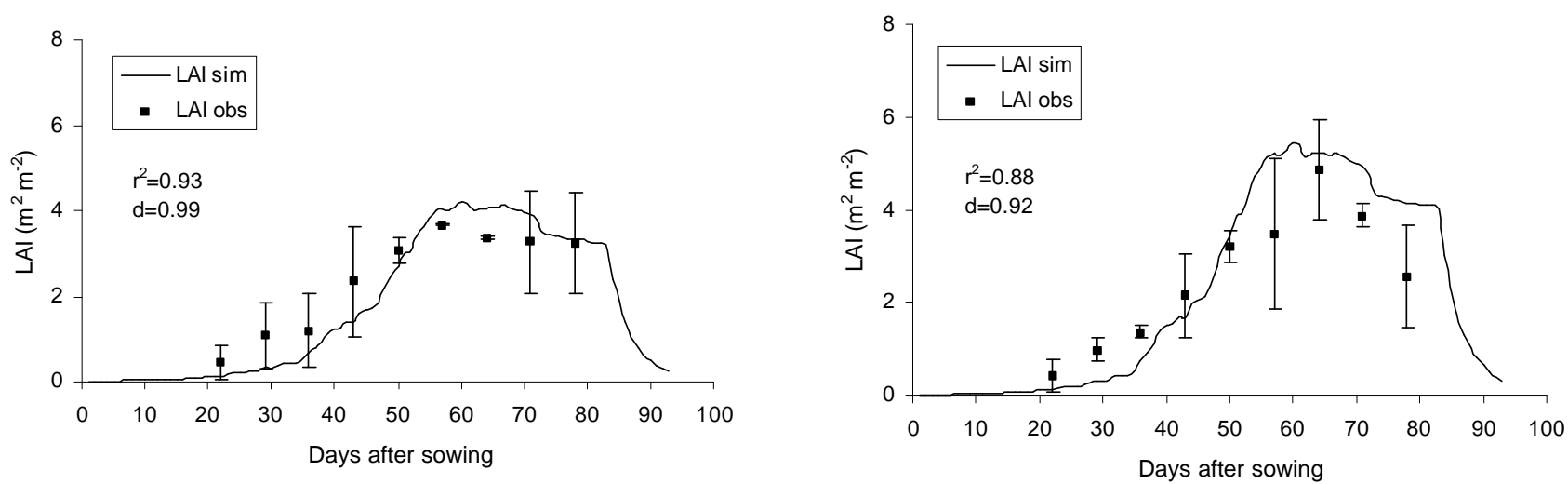

Figure 6 - Leaf area index (LAI) observed and predicted of the dry bean crop, Carioca cultivar, spacing $0.5 \mathrm{~m}$, and fertilization 300 (a) and $500 \mathrm{~kg} \mathrm{ha}^{-1}$ (b) at Santo Antônio de Goiás, GO, Brazil. The amplitude of the vertical lines corresponds to \pm 1 standard deviation.

Table 4 - Observed and predicted yield and yield components of the dry bean crop, Carioca cultivar, row spacings of $0.4 \mathrm{~m}$ and $0.5 \mathrm{~m}$, and fertilization of 300 e $500 \mathrm{~kg} \mathrm{ha}^{-1}$, for Santo Antônio de Goiás, GO, Brazil.

\begin{tabular}{|c|c|c|c|c|c|c|}
\hline \multirow{3}{*}{ Component } & \multicolumn{6}{|c|}{ Fertilization $\left(\mathrm{kg} \mathrm{ha}^{-1}\right)$} \\
\hline & \multicolumn{3}{|c|}{300} & \multicolumn{3}{|c|}{500} \\
\hline & Predicted & Observed & $\operatorname{Dif}(\%)^{1 /}$ & Predicted & Observed & $\operatorname{Dif}(\%)$ \\
\hline \multicolumn{7}{|l|}{ Yield (kg ha-1) } \\
\hline Row spacing $0.4 \mathrm{~m}$ & 2684.0 & 2378.0 & 12.9 & 2603.0 & 2256.0 & 15.4 \\
\hline Row spacing $0.5 \mathrm{~m}$ & 2470.0 & 2153.0 & 14.7 & 2525.0 & 2278.0 & 10.8 \\
\hline \multicolumn{7}{|l|}{$\mathrm{N}^{\circ}$ of grains per pod } \\
\hline Row spacing $0.4 \mathrm{~m}$ & 4.90 & 4.97 & -1.4 & 5.10 & 5.05 & 1.0 \\
\hline Row spacing $0.5 \mathrm{~m}$ & 4.90 & 4.90 & 0.0 & 5.10 & 4.85 & 5.2 \\
\hline \multicolumn{7}{|l|}{ M100 (kg) } \\
\hline Row spacing 0.4 m & $2.30 \times 10^{-2}$ & $2.14 \times 10^{-2}$ & 7.5 & $2.13 \times 10^{-2}$ & $2.07 \times 10^{-2}$ & 2.9 \\
\hline Row spacing $0.5 \mathrm{~m}$ & $2.30 \times 10^{-2}$ & $2.13 \times 10^{-2}$ & 8.5 & $2.11 \times 10^{-2}$ & $2.05 \times 10^{-2}$ & 2.9 \\
\hline
\end{tabular}

${ }^{1}$ Difference $(\%)=[($ Predicted-Observed $) /$ Observed $] \times 100$.

\section{REFERENCES}

BASTOS, E.A. Adaptação do modelo CROPGRO para simulação do crescimento e desenvolvimento do feijão caupi Vigna unguiculata (L.) Walp. sob diferentes condições hídricas, no Estado do Piauí. Piracicaba, 1999. 91p. Tese (Doutorado) - Escola Superior de Agricultura "Luiz de Queiroz", Universidade de São Paulo.

BOOTE, K.J. Concepts for calibrating crop growth models. Crop simulation course. S.I.: s.n., 1994, 13p.

BOOTE, K.J.; JONES, J.W.; HOOGENBOOM, G. Simulation of crop growth: CROPGRO model. In: PEART, R.M.; CURRY, R.B. (Ed.) Agricultural systems modeling and simulation. New York: Marcel Dekker, 1998. p. 651-691.

FARIA, R.T. de; OLIVEIRA, D. de; FOLEGATTI, M.V. Simulação da fenologia e produção do feijoeiro pelo modelo BEANGRO. In: CONGRESSO BRASILEIRO DE AGROMETEOROLOGIA, 10., Piracicaba, 1997. Anais. Piracicaba: Sociedade Brasileira de Agrometeorologia, 1997a. p.140-142.

FARIA, R.T. de; FOLEGATTI, M.V.; FRIZZONE, J.A.; SAAD, A.M. Determination of a long-term optimal irrigation strategy for dry beans in Paraná state, Brazil. Scientia Agricola, v.54, p.155-164, 1997b. Número especial.

GARRIDO, M.A.T. Respostas do feijoeiro às lâminas de água e adubação nitrogenada. Lavras, 1998. 205p. Tese (Doutorado) - Universidade Federal de Lavras.

HOOGENBOOM, G.; JONES, J.W.; BOOTE, K.J. Modeling growth, development, and yield of grain legumes using soygro, pnutgro, and beangro: a review. Transactions of the ASAE, v.35, p.2043-2055, 1992.

HOOGENBOOM, G.; WHITE, J.M.; JONES, J.W.; BOOTE, K.J.; BOWEN, W.T.; PICKERING, N.B.; BATCHELOR, W.D. CROPGRO - Dry bean. In: TSUJI, G.Y.; UEHARA, G.; BALAS, S. (Ed.) Crop models. DSSAT version 3. Honolulu: University of Hawaii, 1994, p.95-281.

JONES, J.W.; MISHOE, J.W.; BOOTE, K.J. Introduction to simulation and modeling. Gainesville: ASPAC - Food \& Fertilizer Technology Center, 1987. 19p. (Technical Bulletin, 100)

JONES, J.W.; WHITE, J.W.; BOOTE, K.J.; HOOGENBOOM, G.; PORTER, C.H. Phenology Module - CROPGRO v.3.7 documentation and source code listing. Gainesville: University of Florida, 1998. 21p. (Research Report, 98-502).
MARTINS, L.A.; SOUSA, F.F. de; RAMALHO, M.A.P.; ABREU, A.F.B. Variabilidade da taxa e da duração do período de acúmulo de matéria seca nos grãos do feijoeiro (Phaseolus vulgaris L.) Ciência e Prática, v.18, p.165-170, 1994.

MEIRELES, E.J.L. Utilização do modelo CROPGRO - dry bean na análise de risco climático da cultura do feijoeiro (Phaseolus vulgaris $\mathrm{L}$.) na região de cerrados. Piracicaba, 2000. 105p. Tese (Doutorado) - Escola Superior de Agricultura "Luiz de Queiroz", Universidade de São Paulo.

ROCHA, J.A.M. Produção do feijoeiro (Phaseolus vulgaris L.) cultivado em populações variáveis quanto ao número e ao arranjamento de plantas. Piracicaba, 1991. 48p. Dissertação (Mestrado) - Escola Superior de Agricultura "Luiz de Queiroz", Universidade de São Paulo.

STONE, L.F.; PEREIRA, A.L. Sucessão arroz-feijão irrigados por aspersão: efeitos de espaçamento entre linhas, adubação e cultivares na produtividade e nutrição do feijoeiro. Pesquisa Agropecuária Brasileira, v.29, p.521-533, 1994a.

STONE, L.F.; PEREIRA, A.L. Sucessão arroz-feijão irrigados por aspersão: efeitos de espaçamento entre linhas, adubação e cultivar no crescimento, desenvolvimento radicular e consumo d'água do feijoeiro. Pesquisa Agropecuária Brasileira, v.29, p.939-954, 1994b.

STONE, L.F.; MOREIRA, J.A.A.; SILVA, S.C. da. Efeitos da tensão da água no solo sobre a produtividade e crescimento do feijoeiro: I. Produtividade. Pesquisa Agropecuária Brasileira, v.23, p.161-167, 1988.

URCHEI, M.A. Efeitos do plantio direto e do preparo convencional sobre alguns atributos físicos de um Latossolo Vermelho-Escuro argiloso e no crescimento e desenvolvimento do feijoeiro (Phaseolus vulgaris L.) sob irrigação. Botucatu, 1996. 131p. Tese (Doutorado) - Universidade Estadual Paulista "Júlio de Mesquita Filho".

VALÉRIO, C.R. Comportamento de cultivares de feijão tipo Carioca em diferentes populações de plantas e espaçamentos entre linhas. Lavras, 1998. 69p. Dissertação (Mestrado) - Universidade Federal de Lavras.

WHITE, J.W.; HOOGENBOOM, G.; JONES, J.W.; BOOTE, K.J. Evaluation of the dry bean model BEANGRO V1.01 for crop production research in a tropical environment. Experimental Agriculture, v.31, p.241-254, 1995.

WILMOTT, C.J.; ACKLESON, S.G.; DAVIS, R.E.; FEDDEMA, J.J.; KLINK, K.M.; LEGATES, D.R.; O'DONNELL, J.; ROWE, C.M. Statistics for the evaluation and comparison of models. Journal of Geophysical Research, v.90, n.C5, p.8995-9005, 1985.

Received January 31, 2001 